\title{
"DIE FRANSE KOLONEL" - VEGGENERAAL GRAAF GEORGES HENRI ANNE - MARIE VICTOR DE VILLEBOIS MAREUIL (1847-1900)
}

Kol dr Jan Ploeger*

\begin{abstract}
"Ardent passions, high hopes and powerful convictions are all necessary to make human minds move".
\end{abstract}

Alexis de Tocqueville (1858)

"Without this passion, and without the courage of his convictions, col Count de VIllebois Mareuil
would not have come to this country, without them, he would not have fought for the cause of
the Boer republics and he would not have laid down his life for the ideals he believed in".
Vice-Admiral H.H. Bierman, SSA, OBE, Commandant-General, SADF, Magersfontein, 14.8.1971

In die dae van onvryheid van geloofsvervolging het die Franse Hugenote in 1688 na die suidpunt van ons wêrelddeel oorgekom om hul gewig in te gooi by die reeds bestaande blanke bevolkingskern en om mee te bou aan die verdere opbou van ons vaderland. Hulle was besoek met hartstog, hoop en kragtige oortuigings en vir hierdie lewensbelangrike ideale bring ons hulle vandag 'n welverdiende hulde.

Van dieselfde gesindheid, wat sy liefde teenoor land en volk aan die suidpunt van Afrika gekenmerk het, getuig meer as twee eeue later die koms van kol Graaf Georges Henri Anne-Marie Victor de Villebois Mareuil (1847-1900) wat 'n vriend van die Boere en hulle ongelyke vryheidstryd was. Hierdie Franse oud-offisier, wat onder die Boere as die "Franse kolonel" bekend gestaan het en deur staats Presidente Marthinus J. Steyn en S.J.P. Kruger met die rang van veggeneraal, die enigste van sy soort onder die buitelandse vrywilligers aan Boerekant, vereer is, het sy eerste lewenslig in die stad Nantes aanskou.

Hy is o.m. militêr aan die beroemde Saint CyrMilitêre Kollege opgelei en in 1868 offisier in die koloniale leër geword. Hy het diens in IndoChina gedoen en in 1871 na sy vaderland teruggekeer wat in die wurggreep van 'n oorlog met die Duitse ryk gewikkel was. In die Derde Republiek het hy sy strafopleiding ondergaan en in 1881 aan 'n veldtog in Tunisië (Noord-Afrika) deelgeneem.

In 1892 het hy Frankryk se jongste kolonel geword en voer agtereenvolgens 'n tweetal linieregimente en 'n regiment van die Vreemdelingelegioen aan.
In 1895 is hy op die reserwelys van offisiere geplaas en aangesien hy graag sy ou beroep wou hervat, het hy - in geval van 'n oorlog tussen die Boererepublieke en die Britse wêreldryk - sy dienste as strateeg aan dr Willem Johannes Leyds aangebied.

Sy oogmerk was dat hy 'n slag vir die Boere teen Frankryk se aartsvyand, Engeland, sou kan slaan waardeur dalk die geskonde Franse roem in ere herstel sou word. Verder het hy die bevordering van sy eie politieke belange beoog. Wat hom verder aangegryp het, was dat hy van gedagte was dat die Boere half-Frans was. Kort voor sy heengaan het hy dan ook teenoor die gewese Franse parlementslid en skrywer Michall Davitt getuig dat hy tot die einde by verwante Boere wou bly. Op grond van dié opvatting het hy ook verklaar dat Frankryk in die uur van nood 'n treffende blyk van bystand aan die Boere verskuldig was. En dan het E.M. de Vogué, die skrywer van die inleiding tot die War Notes The Diary of Colonel de Villebois - Mareuil (London, 1901), die volgende gedagte van die Franse kolonel aangehaal:

\begin{abstract}
"My whole ambition is limited to remaining what I have ever been - a soldier. Besides, the mould in which a soldier's life is formed is too rigid in France to allow a change, once it has been shaped".
\end{abstract}

1. De Villebois - Mareuil in Suid-Afrika. Besiel met bogenoemde ideale, wat ongetwyfeld ' $n$ vaste vorm tydens die verblyf in Suid-Afrika aangeneem het, het die "Franse Kolonel" op 24.11.1899 in Lourenco Marques ("Maputo") aangekom en die treinreis na Pretoria begin. 'n 
Wolk van springkane, wat op die trein neergedaal het, het hom aan sy verblyf in Algerië laat dink. By Komatipoort is die Transvaals-Portugese grens oorgesteek en na 'n doeane-ondersoek is die reis voortgesit. Doringbome het die reisiger weer aan Noord-Afrika en Suid-Spanje laat drink. Op 25.11.1899 het die trein op Waterval-Onder aangekom en die volgende dag is die doel van die reis, Pretoria, bereik waar die kolonel deur die Franse konsul, Aubert, verwelkom is. Op 27.11.1899 het 'n besoek aan staatsekretaris F.W. Reitz gevolg, wat die aangebode dienste aanvaar het. Daarna het die besoeker Pretoria en Johannesburg verken en het hy die Staatspresident ontmoet en hom geleidelik in die bestaande militêre toestand ingewerk. Vervolgens is, in geselskap van 'n ordonans, die trein reis na die Natalse front op 5.12.1899 begin.

2. Uit die Oorlogsindrukke. Ons kan die verblyf van die Franse kolonel van 24.11.1899 tot 7.3.1900 noukeurig volg aan die hand van die War Notes, wat ' $n$ vertaalde weergawe is van sy aantekeninge wat in die Paryse Liberté verskyn het. Kort voor sy vertrek uit Pretoria het De Villebois Mareuil aangeteken:

"The boers are above all free men, conscious of their rights, fearless against authority in defence of those rights, but respectful when the interest of the fatherland is at stake, and on every occasion ready to die for their independence". (pp.30)

Volgens sy sienswyse was die burgers uitstekende ruiters wat, ingeval van bevordering, nie deur die range gegaan het nie, maar aangestel is op grond van hulle maatskaplike invloed. Dit was kolonel De Villebois Mareuil se eerste indrukke. Bekwaam en militêr geskool, soos hy was was De Villebois Mareuil 'n knap skrywer wat sy waarnemings noukeurig saamgevat het. Hy was 'n gebore verkenner wat, op grond van eie waarnemings, sy taktiese optrede voorberei en aan Boereregeneraals, soos genl Louis Botha en ander, voorgelê het. Maar daar het sy frustrasie begin. Kon hy ' $n$ Boeregeneraal met sy Europese tydgenoot vergelyk? Het hy die Boeregeneraal verstaan wat, in teenstelling met sy Europese kollega, 'n krygsraad van offisiere belê het om die sake te bespreek en daaroor te stem? Waar was dié generaal wat persoonlik besluite geneem het?

Dit was slegs ' $n$ paar vrae wat die Franse kolonel gestel het. Sy Europese agtergrond en -opleiding het dan weer tot lof en dan weer tot kritiek gelei. Hy was ontevrede met die wyse waarop die beleëring van Ladysmith verloop het. Besluitloosheid van die Boere en hulle versuim om aan te val, is deur die Fransman, wat planne ontwerp het om die sterkte in te neem, aan kritiek onderwerp. Aan die ander kant het hy tydens die slag van Colenso (15.12.1899) die burgers as knap skutters en uitstekende verdedigers geprys.

Hy is, nadat hy toestemming ontvang het, as 'n gedeeltelik teleurgestelde na die suidelike Vrystaat, waar hy daarin gehoop het om 'n aandeel in die terugdryf van die vyand na die Kaapkolonie sou hê.

Sy gedagte was, dat die duisende burgers wat Kimberley ingesluit het, beter vir ' $n$ aanval in die Kaapkolonie aangewend kan word. En met die oog op die verlede het hy op 12.1. 1900, tydens sy reis na die Vrystaat en in sy dagboek, gekla oor die gebrek aan voorbereidings en verkennings wat hy opgemerk het. Daardeur het al sy stafwerk met die Boereleiers, met uitsondering van genl Louis Botha, waardeloos geword. "With the one exception of General Botha, who continually visits his positions and understands the importance of observations made to him. I have been unable up to now to obtain anything but approbation - never a decision", het De Villebois de Mareuil, gefrustreer soos hy was, gekla. Volgens sy mening het genl P.J. Joubert geen verkenningswerk verrig nie, op besluite van die oomblik staat gemaak en gewag dat die vyand die een of ander besluit neem. Van Pretoria is die kolonel met sy gevolg en muile per trein na Bloemfontein en op Elandsfontein (Germiston) is eetware vir die reis, soos kalkoen, wyn, likeur, vrugte en blikkieskos deur ' $n$ tweetal Franse by die train afgelewer. Die kolonel was in 'n opgewekte stemming en het veel van die toekoms verwag ( $p$ 145). Oor Viljoensdrif, die Vrystaatse doeanepos, is die reis na Kroonstad voortgesit en ' $n$ dag later het die kolonel in Bloemfontein aangekom. Om nege-uur saans was daar geen maaltye meer beskikbaar by die hotel en gevolglik is die toevlug geneem tot die kos wat op Elandsfontein ontvang is.

Die voorkoms van Bloemfontein het die besoeker verras. Die bevolking het kalm voorgekom asof daar geen oorlog verklaar was nie. President Steyn was na Ladysmith en die kolonel sou hom eers later ontmoet. ' $\mathrm{n} W \mathrm{~W}$ is bekom om voorrade mee te vervoer na genl Piet Cronjé se kamp, die eintlike doel van die reis. 
$\mathrm{Na}$ ' $\mathrm{n}$ reis van 'n paar dae het die besoeker, saam met die bekende Léon, wat die Long Tomkanonne versorg het, in die generaal se kamp aangekom en op 22 Januarie 1900 in sy dagboek aangeteken:

"Not tall but stoutly built, an energetic and kindly head, a frank look, an open countenance, and the happy expression of one who feels in his element - such is general Cronje. In time of peace he was to be seen walking about with a stick; somewhat bent, old and tired in expression. But since the war he stands erect. His activity is extraordinary. He visits his positions every day, reprimanding for faults, rectifying errors; very severe or, what is better, very strict" (p. 162).

Twee dae later teken hy, in verband met genl Cronjé se hoofkwartier by die Modderrivier aan:

"About four o'clock yesterday we were in sight of General Cronje's camp, but, from no matter what side you penetrate, you must arrive at the laager to see it. It forms a large rectangle of waggons and tents, with only a few services inside and the general near the angle formed by the front and right sides".

In verband met die beleëring van Kimberley het kolonel de Villebois Marçuil in Februarie 1900 aan die krygsraad voorgestel dat die dorp deur Franse vrywilligers verower word. Die plan is aangeneem, maar telkens weer uitgestel. Dan het hy, aan die begin van Februarie 1900, hoop gekoester dat 'n Long Tom, wat met Franse offisiere by Kimberley aangekom het, die deurslag sou gee.

Op 19 Februarie 1900 het kolonel de Villebois Mareuil in Bloemfontein aangeteken dat hy 'n onderhoud met president M.T. Steyn gevoer het. Hy het daarop aangedring om die Vrystaatse burgers onder 'n eenhoofdige opperbevel te plaas en genl J.H. de la Rey in dié pos te benoem. Verder het hy verklaar dat dit onnodig was om versterkings na die vasgekeerde genl Cronjé te stuur, maar dat genl C.R. de Wet hulle beter kon benut. Hy het aangedring op optrede teenoor Lord Kitchener se bevoorradingstreine.

Op 21 Februarie 1900 het die kolonel planne beraam om ' $n$ eenheid van Franse vrywilligers te vorm. Daarna is hy na Colesberg en vervolgens na genl de Wet se kamp aan die Modderrivier. Op 10 Maart, die dag waarop genl P.J. Joubert hom as ' $n$ veggeneraal aanstel met die opdrag om al die buitelandse vrywilligers as ' $n$ interna- sionale eenheid of legioen onder hom te verenig, lei die nuwe veggeneraal ' $n$ Fransekorps by Abrahamskraal. ' $n$ Week later bevestig die presidente hierdie hoë aanstelling wat de Villebois Mareuil as enigste vreemdelik te beurt geval het.

Op Kroonstad is die legioen gevorm wat uit Franse en Nederlandse, sowel as uit 'n klein Boeregroep onder die Engelse burger. Walter Coleman, bestaan het. Terwyl die veggeneraal se dagboek op 7 Maart 1900 eindig, is dit bekend dat hy op 24 Maart, met ongeveer 100 man onder sy bevel, opgeruk het met die doel om Britse kommunikasielinies by Kimberley aan te val. Boshof was die doel vir sy tog om in dié omgewing 'n brug oor die Modderrivier op te blaas om genl lord Methuen se verbindings te probeer ontwrig. Op die oggend van 5 April het hy met sy vreemdelinge en 'n vyf- en- twintigtal burgers, op die plaas Tweefontein, suidoos van Boshoff, afgesaal. Verder was 'n kommando van 200 burgers onder sy bevel.

3. Die roemryke Einde. Veggeneraal de Villebois Mareuil wou 'n aanval op die swak verdedigde dorp uitvoer. Wat hy nie geweet het nie, is dat genl lord Methuen se 400 manskappe versterk is en 750 man en artillerie besig was om hom en sy getroues te omsingel. Nadat die veggeneraal die aanvallers gewaar het, het hy sy legioen oor twee koppies verdeel. Burgers het stellings op die een en die vreemdelinge op die ander koppie ingeneem.

Terwyl die burgers die aanslag tydig ontkom en nie deur die oormag verpletter is nie, het de Villebois Mareuil besluit om 'n voorbeeld van Franse moed te stel. Sy manskappe het vier uur lank weerstand gebied en slegs die witvlag opgesteek toe ' $n$ aanval met gevelde bajonette op hulle uitgevoer is. Die veggeneraal was op dié tydstip reeds deur 'n bomskerf gewond en tydens die geveg is tien van sy volgelinge gedood, elf gewond en 51 Krygsgevangene geneem.

4. Huldeblyke. Op 5 April 1900 het bogenoemde gebeurtenis plaasgevind en in die inleiding tot die War Notes het E.M. Vogüe o.m. verklaar:

"When he took command, he had but one object in view, one pre-eminent thought which appears many times between the lines of his diary. This thought was no longer for the Boers, but for France and her army. He had sworn to leave in the depths of Africa an im- 
perishable recollection of French bravery; he had resolved to show all - friends or foes how the soldiers of his nation could die. He kept his resolution at Boshoff". (p. xvii)

Verder is bekend dat die veggeneraal op 30 Maart 1900 'n skriftelike beroep aan Michael Davitt oorhandig het, waarin hy o.m. geskryf het:

"Deur die are van 'n groot gedeelte van hierdie mense (die Boere) vloei Franse bloed. In hul uur van nood is Frankryk dus aan hulle 'n treffende blyk van bystand verskuldig".

Van genl Lord Methuen, wat die stoflike oorskot van die "Franse kolonel" met volle militêre eerbewys laat begrawe het, het ook die grafsteen, met 'n Franse teks, as 'n geskenk gekom. Hy het sy teenstander van formaat die hoogste eer laat bewys.

In The Times History of the War in South Africa (deel 4, p. 214) is die volgende gesê:

"The French general deserved a better fate, though he could not have wished for a nobler death, fighting to the end for a cause which he believed to be that of the weak oppressed by the strong".

In Boshof, op die begraafplaas, 'n gedenksteen, in Frankryk monumente in Nantes, Montaign en
Grez- en Bouére. Strate is na die heengane genoem in Parys, Lyon, Madagskar en Algerië. Op 18.3.69 het die Minister van Verdediging, $\mathrm{mnr}$ P.W. Botha, vergesel van die kommandant-generaal van die Suid-Afrikaanse Weermag, genl R.C. Hiemstra, SSA, SM en Vloothoof, Vise-Admiraal H.H. Biermann, SSA, OBE, kranse by die monument in die stad Nantes gelê. By dié geleentheid was o.m. die dogter van wyle veggeneraal de Villebois Marçuil, barones Jaylor (87) aanwesig

Suid-Afrika het op 14.8 .71 sy ereskuld betaal deur die herbegrafnis, met militêre eerbewys, van die stoflike oorskot van veggenl graaf G.H.A.-M. V. de Villebois Marçuil aan die voet van die Magersfontein-monument.

By die geleentheid het die destydse bevelvoerder Maritieme Verdediging en Hoof van die Vloot, Vise-Adminiraal H.H. Biermann, SSA, $\mathrm{OBE}$, o.m. die volgende treffende gedagte in sy huldeblyk uigespreek:

'Ons volk het, in dae van benouenis, sy vriende geken en sal hulle nooit vergeet nie. Vandag huldig ons volk een van sy vriende: Veggeneraal graaf Georges Henri AnneMarie Victor de Villebois Mareuil

* Kol dr Jan Ploeger, SSO Argief en Navorsing, SAW, 1964-1973. Staatshistorikus, RSA, 1973-1983. 